\title{
Sector, landscape or rural transformations? Exploring the limits and potential of agricultural sustainability initiatives through a cocoa case study
}

\author{
Valerie Nelson $^{\mathrm{a}^{*}}$ and David Phillips ${ }^{\mathrm{a}}$
}

Natural Resources Institute, University of Greenwich.

\section{Introduction}

Sustainability in agri-business production and trade is increasingly a focus of development, environmental conservation and responsible business. Yet there are significant challenges including differences in how sustainability is defined, by whom, and whether current interventions are effective, given the nature of the challenges faced.

In this paper, we explore the theory and evolution of sustainability initiatives to better understand their potential and limitations. We compare theories of farm, sector and landscape transformation, and consider fundamental issues relating to the characteristics of multistakeholder initiatives and the embeddedness of global value chains in specific geographies of production. We suggest that transformation theory, developed with respect to socioenvironmental systems and climate adaptation (Pelling, 2011) and particularly distinctions between resilience, transition and transformation, can be applied to elicit insights on the potential of many other tropical agro-commodity sustainability initiatives (Pelling, 2011). Cocoa is used as a test case to explore theories of transformation, with an analysis of the evolution of sustainability initiatives and potential future scenarios, drawing, inter alia, on research with industry stakeholders.

Cocoa is critically important for millions of smallholders and national economies, especially in West Africa, but there are multiple sustainability challenges and corporate concerns regarding global demand outstripping supply (Oomes et al., 2016). In 2014, the International Cocoa Organisation identified multiple industry challenges, such as low productivity, declining soil fertility, poor farm management practices, climate change, etc. There is also widespread poverty in cocoa communities, poor working conditions, child labour issues, and low/volatile farm-gate prices (Cocoa Barometer, 2015). Despite cocoa industry interventions and a real-terms increase in the price of cocoa since 2000, achieving sustainable cocoa remains a significant challenge.

We reflect upon on the potential and limitations of current sustainability initiatives in cocoa (and likely to be relevant to other tropical agricultural commodities facing sustainability 
challenges, such as sugar, tea, palm oil and soya) and conclude by outlining what may be required for more transformative change.

\section{Methodology}

Our study draws on different data sources, including a literature review on social, economic and institutional issues in cocoa and analysis of public reports in covering sustainable cocoa. We reviewed the website-based information of the principal multi-national companies (MNC) engaged in cocoa sustainability (Table 1) ${ }^{1}$. We draw insights from the authors' own research on sustainability standards' impact in Ghanaian, Ecuadorian and Peruvian cocoa. Key informant interviews with stakeholders were conducted, involving semi-structured telephone interviews focused upon perceptions of key challenges and possible scenarios for in sustainable cocoa and their implications for producers. We interviewed four industry representatives from cocoa trading and chocolate manufacturing companies and two sustainability standards' representatives. Key informants were identified via attendance at key cocoa conferences in 2014, and using a snowball approach, plus we identified additional informants from initial interviewees. $^{2}$

\section{Theoretical Perspectives}

\subsection{Farm, sector and landscape transformations}

Sustainability standards have led responses to sustainability challenges in agri-export commodities, including cocoa, for years. Only recently has underpinning theory emerged as to how sustainability standards are anticipated to achieve their goals (Nelson and Martin, 2011). The membership body for 'credible' sustainability standards, ISEAL, has encouraged its members to develop theories of change and studies are beginning to conduct theory based evaluations (e.g. Nelson and Martin, 2013). Such theories articulate diverse pathways which all contribute to farm level transformations for certified farms and producer groups.

The achievements of sustainability standards to date include raised consumer awareness, investment leveraged into good agricultural practices and producer organisation (Nelson and Martin, 2013), plus greater supply chain transparency, assurance and traceability

\footnotetext{
${ }^{1}$ Drawing on information publicly available from 7 cocoa trading/grinding companies; 6 chocolate manufacturing companies; 5 sustainability standard and certifying bodies; 7 multi-stakeholder projects; 10 government and other NGO-led initiatives.

${ }^{2}$ Initial discussions were held with the Chief Executive of the Federation of Cocoa Commerce Limited and one representative of an international cocoa trading company.
} 
(Molenaar et al., 2015). But while 'islands of excellence' exist, poor practices often continue and there are asset entry thresholds which prevent large sections of rural societies from participating (Nelson and Martin, 2013, p104). Demand and supply are not always well balanced. Auditing and compliance can be costly (Blackmore et al., 2012). Competition between standards and gaps in coverage of product groups, sustainability issues, and parts of the supply chain are limiting effectiveness (Vermuelen, 2015). Evidence on the impact of standards is mixed (Blackman and Rivera, 2011), lacking in rigour (Oya et al., 2017) and impacts are context- specific making generalisations difficult (Nelson and Martin, 2013).

Consequently, there has been a shift towards a sector transformation focus. Theorization of sector transformation has been developed (Simons, 2014) in which NGOs raise concerns about sustainability issues, pioneer companies respond seeking to capture market value, these approaches become normalized and are taken up in public legislation, before the cycle begins again. Molenaar, et al., $(2015)^{3}$ describe a similar S-curve of sector transformation (inception phase, first movers, critical mass and institutionalization) involving progress on multiple fronts (sector alignment and accountability, public sector governance, producer organisation, service sector organisation). Such processes are already underway in some industries (Simons, 2014). Sector-based programming has begun, led by organisations such as IDH, a Dutch Sustainable Trade Initiative. Governments are also responding: jurisdictional approaches are emerging in palm oil in Indonesia in which state governments are responding to sustainability by committing to ensure that sourcing within their jurisdictions are sustainable within five years.

While the sector-orientation is promising, more may be needed. Beyond individual commodity issues, landscape partnerships and collaborative governance is needed (Scherr et al., 2017). Landscape approaches are already widespread in international conservation programming, but are now being taken up in sustainable sourcing, to meet threats to ecosystem services from land degradation and commercial tree plantations. Business in Africa is increasingly engaging with sustainable landscape management in their operations and supply chains (Gross et al., 2015) ${ }^{4}$, considering the wider physical and social landscape ('Scope 4' in

\footnotetext{
${ }^{3}$ http://sectortransformation.com/wp-content/uploads/2015/03/sectortransformationreport.pdf (page 4). Aidenvironment ,NewForesight and IIED have developed a groundbreaking new holistic Sustainable Sector Transformation Model commissioned by the IFC, the Dutch Ministry of Affairs, SECO and IDH the sustainable trade initiative. 
responsible business parlance) in which their supply chains are embedded. They are recognizing the need to engage with a wider set of stakeholders, including poorer smallholders, and addressing food and livelihood issues (Kissinger et al., 2013) and seeking to eliminate bad practices (Sustainable Food Lab, 2012). ${ }^{5}$

Landscape approaches seek to achieve landscape-scale change, including environmental transitions (e.g., restoration of forests) that balance competing land use demands (Kissinger et al., 2013; Sayer et al., 2016; Reed et al., 2015). A 'landscape transition curve' can be mapped and there are common processes of land management intensification and infrastructural expansion which can be identified, looking firstly at remote areas through intermediate zones to cities (Sayer et al., 2016). Such approaches focus upon land use goals primarily from an environmental perspective, although stakeholder negotiations on objectives are specific to place (Sayer et al., 2016). The quality of business participation needs to improve, but the business case for landscape partnerships is still not proven and improved business manager facilitation skills will be needed as collaborative governance is challenging (Scherr et al., 2017). However, there are other, more fundamental, critiques of MSIs, beyond the instrumental.

\subsection{Political economy issues and the emerging critique of Multi-Stakeholder}

\section{Initiatives}

Economic globalisation has involved a loss of power from the local with land governance shifting from government and community control to extra-territorial actors, including MNCs (Sikor et al., ., 2014). Each value chain and multi-stakeholder initiative (MSI) is increasingly embedded in a political economy of multiple scales. Studying fair and ethical trade in South Indian tea and coffee plantation zones, Neilson and Pritchard (2010, p1834) define such schemes as sets of 'introduced discourses and practices within producer communities' that themselves are institutionally embedded within particular sociospatial environments'. While individual farms can benefit, uneven implementation means that fair and ethical trade schemes completely ignore the smallholder sector and plantation abandonment in Kerala and essentially are neglecting regional economic and governance institutions (Neilson and Pritchard, 2010). Livelihoods within the broader political economy and the transnational linkages along value chains should be unpacked (Bolwig et al., 2008, p2-3). The dynamic

\footnotetext{
${ }^{5}$ http://www.sustainablefoodlab.org/wp-content/uploads/2015/12/landscape-deck-for-web-v3.pdf
} 
nature of value chain actors' terms of integration in global value chains also needs analysis. Powerful actors can impose new standards and mobilized labour can exerts agency from the bottom up (Bolwig et al., 2008, p2). Understanding the changing contexts within which MSIs are embedded in the vertical dimension (value chains) and horizontally (in territories) is necessary, as there are differentiated social relations and bargaining capabilities, plural value systems and changing value chain governance and terms of integration.

The characteristics of MSIs and the developmental implications also require attention: farm, sector and landscape sustainability initiatives all share a common reliance upon MSIs as the key strategy for engaging diverse actors and realising change. Yet reconciling competing interests is hardly a straightforward managerial issue. A new strand of academic research is exploring the politics of MSI. MSI participants have differing capabilities and access creating process inequalities (Tallontire et al., 2013; Fransen and Kolk, (2007). Organisations of the global north dominate standard governance and there are imbalances between civic organisations and industry (Reinicke et al., 2000). Cheyns (2011, p23) finds that MSIs can repress 'open political debate' with their emphasis on 'urgency and pragmatism', prioritizing 'strategic engagement' at the expense, paradoxically, of local peoples' participation. Where local people focus on issues of justice, MSIs adopt the language of 'satisfying need', marginalizing personal attachments and emotions relating to lived experience (Cheyns, 2011, p8). While they intend to give voice to multiple actors and to facilitate social inclusion, they can struggle to effectively recognize 'pluralism in defining the common good' (Cheyns, ibid, p23). There is an ongoing 'battlefields of ideas' associated with the contested processes of MSIs in defining sustainability and the scope of responses, which private standards' actors and agribusiness tend to dominate (Nelson and Tallontire, 2014). Technical expertise is given primacy, as are technocratic interpretations of sustainability, creating contingent spaces for participation by less powerful groups (Tallontire et al., 2013).

A recent report on MSIs as new instruments of global governance, finds that 45 MSIs set international standards governing corporate or government conduct ${ }^{6}$ (MSI Integrity, 2017). MSIs share similar designs, but unevenly cover global industry and a majority of MSIs do not meaningfully engage communities affected by participating company operations in governance or implementation processes.

More research is therefore urgently needed on the governance and politics of MSIs, in executive, judicial and legislative dimensions (Tallontire et al., 2011). While MSIs may have

\footnotetext{
${ }^{6} \mathrm{http}$ //www.msi-integrity.org/the-new-regulators-new-report-on-the-global-landscape-of-standard-setting-msis/
} 
noble objectives, this does not mean their effectiveness can be taken for granted. They may have the potential to secure significant gains in coordination and action, but this does not necessarily equate with equity in process and outcome.

\subsection{Understanding socio-environmental transformations}

While there is extensive rhetoric on transitions and transformations in sustainable sourcing, we suggest that emerging theory and practice in sector and landscape approaches lack awareness of the politics of transformation. A theoretical framework developed in relation to climate change adaptation (Pelling, 2011) is proposed here as a means of foregrounding political economy analysis as contribution to the development of theory on sustainable rural development.

Pelling (2011), drawing upon extensive environmental and social science theory, ${ }^{7}$ distinguishes between three different visions of adaptation. Firstly, adaptation as resilience is defined as 'functional persistence in a changing environment'. Secondly, adaptation as transitions refers to the 'exercise of rights within the established regime'; and, thirdly, adaptation as transformations involves the 'reconfiguring the structures of development' (Pelling, 2011, p51). Seeking a continuation of the status quo (resilience) in situations of significant inequality is inherently problematic (Pelling, 2011). Incremental changes are possible in transitional approaches, but more profound change (transformational) means altering the 'the distribution of rights and responsibilities and visions of development across society' (Pelling, 2011, p74). We apply this framework here to analyse the ambition of evolving sustainability initiatives and to draw insights on their likely effectiveness. Employing cocoa as a test case, the insights are relevant to other agribusiness commodities such as oil palm, sugar, and soybeans.

\section{Findings}

\subsection{Evolving Sustainability Initiatives in West African Cocoa}

The Fair Trade movement was the first to bring issues concerning cocoa producer welfare to wider consumer attention in Europe and the USA (1990s). Partnerships with

\footnotetext{
${ }^{7}$ Resilience to climate change is an interpretation that draws upon theory of social-ecological systems (see, for example, Gunderson and Holling, 2002; Walker and Salt, 2006) and on theories of social learning and selforganisation. Pelling explores adaptation as transition, drawing on theoretical work on socio-technical transitions (e.g. Seyfang and Smith, 2007). Adaptation as transformation draws upon risk society theory (Beck, 1992), Social contract theory with its long history in Western political philosophy and Human Security theory.
} 
companies, such as the Divine Chocolate Company in Ghana and the Co-Operative supermarket group, led to the emergence of Fairtrade-labelled chocolate products in the UK. Green \& Blacks was the first company to produce and market organic certified chocolate in 1991. ${ }^{8}$ NGOs and media reports highlighted additional social concerns in the 2000s, especially child and slave labour in cocoa. ${ }^{9}$ MNCs have responded with governmental and international collaborations, including with the International Labour Organisation (ILO). The International Cocoa Initiative (ICI) (2002) provided a platform for action on the eradication of the worst forms of child and forced labour. The Cote d'Ivoire government established the National Committee for the Fight against Trafficking and Child Exploitation (2006).

Certified products and volumes increased significantly in the 2000s. Fairtrade International, a producer certification and product labelling system, moved into the mainstream developing new standards allowing for the participation of plantation production and the marketing of own brand products by supermarkets. Several companies ${ }^{10}$ transferred entire product lines to so that sales increased significantly. Concerns for environmental issues associated with tropical commodity production also grew. The environmental labelling and certification initiative, Rainforest Alliance (RA), launched its cocoa programme in Ecuador in 1998, eventually reaching over 120,000 cocoa farms in 11 countries. Several companies cooperated on a Sustainable Agriculture Initiative (SAI) Platform (2002), a non-governmental organisation, to catalyse collaboration on sustainable agricultural practices. A business-tobusiness standard (UTZ Certified) was founded with industry partners (2007), and launched a cocoa programme targeting the mainstream mass of producers (Laven and Boosma, 2012, p16). By 2012, sustainability standards certified an estimated 22 per cent of the world's cocoa production, of which approximately one-third was sold as compliant to standards (accounting for 10 per cent of global cocoa exports) (Potts et al., 2014).

Private sector responses beyond certification have included the formation of the World Cocoa Foundation (WCF, 2000) to minimize negative consumer reaction and enhance cocoa quality and production, funding ILO cocoa labour studies and a Sustainable Tree Crop Program $(\mathrm{STCP})^{11}$. Corporate investments scaled up in the late 2000 s and early 2010 s when financial commitments made by individual multi-nationals increased, most especially since 2008 . These

\footnotetext{
${ }^{8}$ Since bought by Cadbury, now Mondelez International.

${ }^{9}$ More recent global media pieces by BBC 2011 and CNN 2014 have revealed a continuation of child labour on cocoa farms.

10 including Cadburys and Nestlé

${ }^{11}$ Implemented with the International Institute for Tropical Agriculture (IITA).
} 
investments focused upon improving productivity and quality, and have sought to raise smallholder living standards in their own supply chains.

In the mid-2000s, Cadbury commissioned research into the social and economic sustainability of their chocolate value chains, leading to a Cadbury Cocoa Partnership (CCP) in 2008 (Barrientos 2011). Forty-five million pounds were committed for investment over ten years in cocoa farms in Ghana and other sourcing regions. Cadbury was the first large chocolate manufacturer to commit its leading brand to Fairtrade certification in 2009. Since 2010, more corporate programmes have been initiated, focussing on productivity, yields, and quality, with some funding targeted at community development programmes. At the time of our stakeholder consultations (2014), companies had committed more than $\$ 800 \mathrm{~m}$ and donors have also invested in relevant programming, mainly intended for Ghana and Côte D'Ivoire.

However, key informant interviewees consistently signalled dissatisfaction with respect to the effectiveness of the interventions they have witnessed. 'Productivist rationalities', i.e. approaches giving productivity primacy above all else, have also received academic critique (Lemeilleur, et al., 2015), because cocoa specialisation carries risks for smallholder households, due to the additional input and labour costs involved and the latter can have gender and child labour dimensions.

Collaborative partnerships in a pre-competitive paradigm are generally viewed by industry stakeholders as being indispensable for achieving sustainability (MITSloan, 2014). This trend for collaborative action amongst industry actors, and partnerships with NGOs, donors, and governments is particularly pronounced in cocoa. Early Public-Private Partnerships (PPP) involved bilateral relationships, between companies and NGOs, or between a company and a sustainability standard. Multi-actor collaborations are now increasingly common, with financial contributions from multiple major companies and diverse delivery partners, often supplemented by donor funds. International industry partnerships also support PPPs to strengthen farmer capacity ${ }^{12}$. While sustainability standards continue to play a role, many companies are starting to look beyond certification to in-house initiatives for market differentiation (Watanatada and Mak, 2011). An extension of an existing partnership between Fairtrade and Cadbury was announced in December 2016 now covering all Cadbury projects in the UK and Ireland by 2019. This is intended to scale up coverage (a sum of $\$ 400$ million

\footnotetext{
12 The World Cocoa Foundation (WCF), an international industry membership organisation, supports programmes through farmer-level PPPs.
} 
has been earmarked for investment by 2020), but there are existential risks involved for Fairtrade as the cocoa manufacturer's CocoaLife brand will now take precedence ${ }^{13}$.

Most PPPs invest comparatively little in social development projects, although there are some signs of change. ADM's Socially \& Environmentally Responsible Agriculture Practices (SERAP) Program includes projects established based upon community-level priorities in Cote d'Ivoire and Ghana, and is seeking to engage with non-landowners. ${ }^{14}$

A new level of pre-competitive collaboration in West African cocoa has also now emerged with the formation of the sector-wide CocoaAction. It seeks to align the cocoa sustainability efforts of large cocoa-related companies. ${ }^{15}$ National governments in Ghana and Cote D'Ivoire have given endorsements and the private sector has developed national cocoa development plans. ${ }^{16}$ It has published a voluntary, industry strategy with a joint vision, theory of change and results framework ${ }^{17}$. This will support scaling efforts, but senior cocoa sector executives interviewed queried the potential impact of the CocoaAction plans published in 2014, which target 300,000 farmers in West Africa, on productivity and community development, which is a relatively small proportion of cocoa smallholder farmers in West Africa. ${ }^{18}$ Assuming yield increase and community development targets are met by the year 2020 this still means only approximately one fifth of producers will have been affected, with investment not reaching the remaining farmers, and also no clear driver for price rises for farmers. An international voluntary cocoa standard is also being developed by the European Committee for Standardisation (CEN) and International Standards Organisation (ISO), which could reach up to 50 million cocoa farmers, the quality of farmer representation is not clear (Steijn, 2012).

\section{Stakeholder perspectives on cocoa sustainability scenarios}

Most industry stakeholders interviewed feel that governments should respond to infrastructure, farmer and market organisation challenges, and while industry and donors could assist, they are not a substitute for government. The cocoa industry is aware of the underlying

\footnotetext{
${ }^{13}$ http://www.fairtrade.org.uk/en/media-centre/news/november-2016/cocoa-life-and-fairtrade-partnership

${ }^{14}$ Hendriksz, M. pers comm 2014

${ }^{15}$ Companies: ADM; Armajaro; Barry Callebaut; Blommer; Cargill; Ecom; Ferrero; Hershey; Mars,; Mondelez, Nestle, and Olam.

${ }^{16}$ Joint agreements have been signed between members of CocoaAction and the governments of Cote d'Ivoire and Ghana.

${ }^{17} \mathrm{http} / /$ www.worldcocoafoundation.org/wp-content/uploads/CocoaAction-Annual-Report-2015-English.pdf

${ }^{18}$ The Cocoa Barometer 2015 calculates that 500,000 farmers will be trained by major traders and grinders (excluding ADM). In addition, 150,000 farmers are covered by the chocolate manufacturers. However, there could be double counting in these numbers. In total these figures represent approximately $12 \%$ of the total estimated 5.5 million cocoa farmers in West Africa. To achieve their sustainable sourcing commitments companies would need to train three times this number.
} 
institutional and governance challenges, but still hesitates to invest further. Interviewees outlined a series of possible scenarios for cocoa futures.

Firstly, consumption could decrease with time, with smaller quantities of cocoa being produced and chocolate becoming a luxury item. Prices would rise (Moss, 2014). Companies will change the types of products sold, reduce product size, and increase the use of fillers and cheaper ingredients such as more sugar and vegetable fats. Secondly, several private sector and NGO interviewees envisage a scenario in which land concentration occurs over the next 10 to 15 years, large percentages of ageing smallholder farmers retire, and those with more ability to invest replant some land, including shade trees, and create diversified, larger farms. Decades of under-investment in roads, communications, soft loans and other supporting services would need to be reversed though and complex land rights situations in West Africa overcome. Social protection and employment creation measures would be needed. This scenario could underestimate the full cultural value of smallholder farming for rural communities.

A third scenario is the potential for an increase in large-scale commercial cocoa plantation farming - this is already occurring in Latin America. West African supply looks unlikely to meet strong confectionary consumption growth in Asia and other emerging markets, so chocolate makers and producers will increasingly look to Latin America and Asia (Terazono, $2014)^{19}$.

A fourth scenario is a hiking of cocoa taxes, associated with 'real' transparency, making larger sums available for investment in public goods and services. An international levy on cocoa has also been mooted (ICCO, 2014). A small surcharge at the 'community trading level' could facilitate reinvestment in cocoa communities (Cocoa Barometer, 2015). These are relatively minor profit redistribution measures in the contexts of extreme poverty and tackling cocoa prices more generally and share of incomes is also necessary (Cocoa Barometer, 2015).

A fifth scenario is increased investment in diversified livelihood strategies for existing smallholder farmers. Cocoa companies are starting to consider with diversification for income and environmental benefits for farmers. RA is researching non-timber species that farmers could grow ${ }^{20}$ and in collaboration with Olam, RA has supported combined income stream approaches in Ghana (Kissinger et al., 2013). Timber and cocoa can be intercropped, with

\footnotetext{
${ }^{19}$ Examples include privately owned United Cacao operating in Peru (aiming to plant 4000 hectares), Agro Nica Holdings in Nicaragua, and family-owned ROIG Agro-Cacao in the Dominican Republic (Terazono, 2014). In West Africa, Tropical Farms Limited in Sierra Leone has invested in a 4000-hectare cocoa plantation (CTA, 2014). 20 Schroth, G. pers comm 2014.
} 
environmental and economic benefits (Schroth and Harvey 2007). Oomes et al., (2016) argue that such livelihood diversification is the real solution to tackling poverty.

\section{Reflections upon theory and practice}

Stakeholder interviews revealed little articulation of a pathway to sustainability in which rural communities are central actors in defining sustainable land management and economic development on their own terms. Plural values, issues of economic justice, personal attachments (to places, community, livelihood activities and environments) and the quality of MSI processes are not visible in the search for sustainability solutions.

There is now a move towards sector and landscape approaches, although programming lags behind the rhetoric and so more evaluation is needed of effectiveness and impacts, and including on the quality of MSI processes, given the prevalence and lack of scrutiny of this centrally important mechanism. Farmer organisation in West Africa is relatively weak, which suggests that the representation of smallholders could be particularly problematic. The Cocoa Barometer (2015) already states that farmers tend to be under-represented in multi-stakeholder initiatives and PPPs in cocoa.

Sector and landscape approaches in sustainability sourcing both share a starting point of local people as cocoa farmers, but this framing could impose the priorities of the industry, circumscribing potential responses. For these communities, the starting point should rather be what livelihood and economic development scenarios there could be. A narrow focus on cocoa specialization further exposes cocoa producers to market risks especially price depression results from productivity investment and over-supply (Oomes et al., 2016). Rather than thinking of sustainability 'choice spaces' for cocoa farmers (Ros Tonen et al., 2015), such concepts should be applied to rural development pathways more broadly.

The operational challenges of landscape approaches are substantial (Reed et al., 2015). Programmers frequently over-estimate their influence over the drivers of unsustainable land use (Colfer et al., 2011) and the business case for landscape level programmes is still unproven (Gross et al ., 2014). Presented as a 'new management paradigm to achieve sustainability', in some cases, landscape concepts are little more than marketing slogans for some observers (Rozemeijer, 2008). Landscape approaches risk increasing centralized control over the balance of objectives in planning, with the notion of negotiated outcomes therefore being somewhat meaningless (Rozemeijer, 2008). In such scenarios of increased centralization, sustainable landscape initiatives would merely reinforce the existing trend of power moving to extraterritorial sources (Pelling, 2011). This is a risk in cocoa sustainability initiatives, in which 
multi-nationals, international NGOs, donors, have tended to dominate, and while producer governments are involved there is often insufficient accountability to the local level. Stakeholders may focus on the 'pragmatic' meso level where stakeholders' management objectives may overlap and there are manageable entry points, but, this pragmatism could repeat the failures of the past if they do not sufficiently address the power inequalities at work beyond the landscape (Rozemijer, 2008).

Using Pelling's definitions (Pelling, 2011, p51) we suggest that most current cocoa and other agro-commodity sustainability initiatives, whatever their focus, fall into the category of resilience-oriented interventions (functional persistence as the environment changes), or at most could be considered as transition-oriented (increased exercise of rights, but within an established regime). Existing initiatives have developmental value leveraging investment into sustainable agricultural practices and facilitating coordination between powerful players, leading to scaling and the use of new technology. A sustained industry is a significant development contribution, particularly in a climate change context. But, as with any 'resilience' oriented intervention, they do not challenge power relations and so carry risks of reinforcing power inequalities. The continuing focus on cocoa, and on cocoa productivity, while neglecting diversification and wider rural governance issues carries such risks.

While some might argue that sector-based approaches are transitional or even transformational in nature, if Pelling's definitions are applied then we suggest that transformational change requires more than synergies across a system (e.g. in the coordination and delivery of services) etc. It means changes in the distribution of rights and responsibilities and significant improvements in governance - ultimately it means farmer and community political empowerment to drive economic development.

Transitional approaches enable actors to exercise their rights within the existing regime, which requires greater procedural justice (after Pelling, 2011). Cocoa MSIs are being initiated and while farmer consultation may increase, this is not the same as full participation in MSI governance and implementation and so the risk is that these will inevitably primarily serve the interests of those driving the MSI, namely industry actors. The social differentiation of rural territories is not well addressed by sector-specific MSIs and their scope is also often far too narrow, failing to challenge producer governments to significantly reform their cocoa governance systems, on the use of tax returns, land tenure and reform processes etc.

Existing sustainability cocoa initiatives do not adequately challenge governance practices and leverage investment in alternative livelihood opportunities, such that diversified smallholders and communities can claim greater rights, have greater voice and achieve 
improved livelihood options. Transformational approaches would give more serious consideration of political economy and governance issues, with smallholders and community members having a greater role in driving development processes per se, not just in externally driven cocoa initiatives. Changes are needed in the structural rules of the game, co-construction of policy processes, and support for collective organisation and mobilization (Utting, 2014, pvi). Political and policy space could be opened-up by breaking out of the cocoa box and refocusing upon what is required for rural political-economic transformations, i.e. productive innovation and institutional change, addressing systemic issues and scaling up solidarity approaches to economic exchange (UNRISD, 2016).

\section{Conclusion}

Sustainable cocoa initiatives have evolved from being farm- to sector- and landscapeoriented. For many years, NGOs and industry actors have noted cocoa unsustainability, but the challenges remain significant. Using Pelling's climate adaptation framework, we find that many previous and current approaches largely constitute resilience-oriented interventions, and potentially risk reinforcing inequalities in contexts of increasing market concentration. Sectoral and landscape approaches potentially offer ways to scale up sustainability responses, enabling greater coordination (mainly amongst more powerful actors) through multi-stakeholder partnerships. However, MSIs can struggle to accommodate plural values and visions, personal attachments and this extends to the negotiation of objectives and quality of representation, and may marginalize arguments relating to economic justice and alternative rural development pathways. The cocoa crop is the primary point of entry, with broader understandings of rural households, livelihoods, communities and territories given less attention. Gaps in responsibility for rural infrastructure and public services provision are unresolved and rural poverty issues persist. Sustainable productive transformation and institutional change is challenging in situations of significant rural governance deficiencies, but cocoa industry players themselves

are seeing the limitations of current approaches and are looking for new responses. A reorientation of stakeholder responses to the 'cocoa crisis' is needed, particularly from national and local governments. 


\section{References}

Barrientos S, 2011. Beyond Fair Trade: Why are Mainstream Chocolate Companies Pursuing Social and Economic Sustainability in Cocoa Sourcing? Paper to ILO/IFC Better Work Conference October 2011

Beck U, 1992. Risk Society: Towards a New Modernity. Sage Publications Ltd, London. Blackman A., Rivera, J. 2011. Producer-level benefits of sustainability certification. Conservation Biology, 25 (6), 1176-1185.

Blackmore E, Keeley, J, Pyburn, R., Mangnus, E, Chen, L, Yuhui Q, 2012. Assessing the benefits of sustainability certification for small-scale farmers in Asia. IIED Natural Resource Issues, London: International Institute for Environment and Development Bolwig S, Ponte S, du Toit A, Riisgaard L, Halberg N et al., 2008. Integrating Poverty, Gender and Environmental Concerns into Value Chain Analysis - A Conceptual Framework and Lessons for Action Research. Development Policy Review, 2010, 28 (2): 173-194

Cheyns E. 2011. Multi-stakeholder initiatives for Sustainable Agriculture: Limits of the 'Inclusiveness' Paradigm. In: Governing through standards: Origins, drivers and limits. Ponte S, Vestergaard J, Gibbon P (eds). London: Palgrave.

Colfer CJP, Pfund JL eds., 2011. Collaborative Governance of Tropical Landscapes. Earthscan, London, UK. ISBN 9781849711777.

Cocoa Barometer. 2015. Looking for a living income. Cocoa Barometer Consortium. . Accessed 25.06.2017. http://www.cocoabarometer.org/Download_files/Cocoa\%20Barometer\%202015\%20P rint\%20Friendly\%20Version.pdf

CTA, 2014. Prospective trends in the future location of global cocoa production. CTA Agritrade 25.07.2014 Available at: http://agritrade.cta.int/Agriculture/Commodities/Cocoa/Prospective-trends-in-thefuture-location-of-global-cocoa-production

Fairtrade Foundation, 2011. Fairtrade and Cocoa. Commodity Briefing, Fairtrade Foundation London

Fransen LW, Kolk A, 2007. Global Rule Setting for Business: A critical Analysis of Multistakeholder Standards. Organization 14 (5), 667-684. 
Gross L, Negra C, Brasser A, Fox L Kissinger G, Parr M, Amis M, Sikoyo G, Fox R, Athanas A, and Mwaniki W. 2014. Engaging Business for Integrated Landscape Initiatives in Africa. TerrAfrica, Landscapes for People, Food and Nature. EcoAgriculturePartners. Accessed on 15.01.2017. http://ecoagriculture.org/wpcontent/uploads/2014/09/EngagingBusinessforIntegratedLandscapeInitiativesinAfrica1.pdf Gunderson LH, Holling CS. eds. 2002. Panarchy: Understanding Transformations in Socialecological Systems. London: Island Press.

ICCO 2014 Report on the World Cocoa Conference 2014 Available at http://www.icco.org/about-us/international-cocoa-agreements/cat_view/81-worldcocoa-conference-amsterdam-2014.html

IIED, 2012. Certified Cocoa: scaling up farmer participation in West Africa. International Institute for Environment and Development/Sustainable Food Lab 2012

Kissinger G, Brasser A, Gross L, 2013. Reducing Risk: Landscape Approaches to Sustainable Sourcing. Washington, DC. Landscapes for People, Food and Nature Initiative. Accessed on 15.03.2016, available on: http://ecoagriculture.org/wpcontent/uploads/2013/04/Reducing-Risk_-Landscape-Approaches-to-SustainableSourcing-Scoping-Study.pdf.

Laven A, and Boosma M, 2012. Incentives for sustainable cocoa production in Ghana: Moving from maximizing outputs to optimizing performance. Royal Tropical Institute. Available at: http://www.worldcocoafoundation.org/wpcontent/uploads/files_mf/laven201297.pdf

Lemeilleur S, N'Dao Y, Ruf F. 2015. The productivist rationality behind a sustainab certification process: evidence from the Rainforest Alliance in the Ivorian cocoa sector. International Journal of Sustainable Development, 18 (4): p310-328.

MITSloan Management Review, 2014. Joining Forces: Collaboration and Leadership for Sustainability. The Boston Consulting Group, United Nations Global Compact. Research Report, January 2015.

Molenaar JW, Gorter JHeilbron,L, Simons, L, Vorley B., Blackmore E., Dallinger J. 2015. Sustainable Sector Transformation: How to drive sustainability performance in smallholder-dominated agricultural sectors? White Paper 1. Commissioned by IFC.

Moss R, 2014. The World Is Running Out of Chocolate. The Huffington Post online 17.11.2014 MSI Integrity and the Duke Human Rights Center at the Kenan Institute for Ethics, 2017. The New Regulators? Assessing the landscape of multi-stakeholder initiatives. Findings from a database of transnational standard-setting multi-stakeholder initiatives. June 
2017. Available at: http://www.msi-integrity.org/the-new-regulators-new-report-onthe-global-landscape-of-standard-setting-msis/

Neilson J and Pritchard B, 2010 Fairness and ethicality in their place: the regional dynamics of fair trade and ethical sourcing agendas in the plantation districts of south India'/ Environment and Planning A 2010. 42, 1833 - 1851. Doi:10.1068/a4260.

Nelson V, Martin A, 2011. Impact evaluation of social and environmental voluntary standard systems (SEVSS): using theories of change. Natural Resources Institute, University of Greenwich Report: Chatham, http://www. org/projects/tradestandards/docs/final_dfid_paper_on_using_theories_o f_change_in_ie_of_standards.pdf.

Nelson V, Martin A, 2013. Final Technical Report: Assessing the poverty impact of sustainability standards. NRI Report, Chatham: UK.

Nelson V, Opoku K., Martin A, Bugri J, Posthumus H, (2013) 'Final Report: Assessing the poverty impact of sustainability standards: Fairtrade in Ghanaian cocoa'

Nelson V, and Tallontire A, 2014. Battlefields of ideas: changing narratives and power dynamics in private standards in global agricultural value chains. Agriculture and Human Values September 2014, 13 (3) 481-497

Oomes N, Tieben B, Laven A, Ammerlaan T, Appelman R, Biesenbeek C, Buunk E, 2016. Market Concentration and Price Formation in the Global Cocoa Value Chain: Final Report. Amsterdam, 15 November 2016. Commissioned by the Ministry of Foreign Affairs, Netherlands. Accessed on 15.03.2017, Available at: http://www.seo.nl/uploads/media/2016-

79_Market_Concentration_and_Price_Formation_in_the_Global_Cocoa_Value_Chai $\underline{\text { n.pdf }}$

Oya C, Schaefer F, Skalidou D, McCosker, Langer L, 2017. Effects of certification schemes for agricultural production on socio-economic outcomes in low- and middle-income countries: A systematic review 3ie Systematic Review 34. London: International Initiative for Impact Evaluation (3ie).

Pelling M, 2011. Adaptation to Climate Change: From resilience to transformation Routledge, London: UK.

Potts J, Lynch M., Wilkings A, Huppé G, Cunningham M, Voora, V, 2014. The State of Sustainability Initiatives Review 2014: Standards and the Green Economy. A Joint Initiative of ENTWINED, IDH, IIED, FAST, IISD 
Reed J, Deakin L, Sunderland T, 2015. What are Integrated Landscape Approaches and how effectively have they been implemented in the tropics: a systematic map protocol. Environmental Evidence, 4, 1-7.

Reinicke WH, Benner T, Witte JM, Whitaker B, Gershman J, 2000. Critical choices: The United Nations, Networks, and the future of global governance, Ottawa, International Development Research Centre.

Ros Tonen MAF, Van Leynseele YPB, Laven A, Sunderland T, 2015. Landscapes of Social Inclusion: Inclusive Value Chain Collaboration through the lenses of Food Sovereignty and Landscape Governance'. European Journal of Development Research 27 (4): 523 - 540. September 2015; doi:10.1057/ejdr.2015.50

Rozemeijer N, 2008. A landscape approach guiding a multiple stakeholder process to find alternatives for illegal chainsaw lumbering in Ghana - enhanced effectiveness or more confusion? Wageningen International December 2008. Available at: http://edepot.wur.n1/3522

Sayer J, Margules C, Boedhihartono A, Sunderland T, Langston J, Reed J, Riggs R, Buck L, Campbell B, Kusters K, Elliot C, Minang P, Dale A, Purnomo H, Stevenson J, Gunarso P, Purnomo A. 2016. Measuring the Effectiveness of landscape approaches to conservation and development. Sustainability Science. p1-12 doi:10.1007/s11625016-0415-z. Accessed on 1.03.2017, available at: http://ecoagriculture.org/publication/measuring-the-effectiveness-of-landscapeapproaches-to-conservation-and-development/

Shames S, Heiner K, Scherr, S 2017. et al., (2017) Public Policy Guidelines for Integrated Landscape Management. Landscapes for People, Food and Nature. EcoAgriculture Partners.

http://ecoagriculture.org/wp-content/uploads/2017/01/Public-Policy-Guidelines-for-ILMJanuary-2017-Final.pdf

Schroth G, Harvey C. (2007) Biodiversity Conservation in Cocoa Production Landscapes: An Overview. Biodiversity and Conservation 16 (8) 2237-2244

Seyfang G, Smith A, 2007 Grassroots innovations for sustainable development: Towards a new research and policy agenda. Environmental Politics. 16 (4) 584 - 603

SFL (2012) 'Sustainable Sourcing'. Available at:

http://www.sustainablefoodlab.org/newsletter-january-2015/31-general/282-scope$\underline{\text { 4?utm_source }=S F L+M a i n+C o n t a c t s+L i s t \& u t m \_c a m p a i g n=a 6 e 4471 e 56-}$ 
Food_Lab_News_July_20137_22_2013\&utm_medium=email\&utm_term=0_03d987 41b6-a6e4471e56-329209921 (Accessed 28.01.2015)

Sikor T, Auld G, Bebbington AJ, Benjaminsen TA, Gentry BS, Hunsberger C et al.,., Global land governance: From territory to flow? Current Opinion in Environmental Sustainability. 2013 Oct;5(5):522-527. Available from, DOI:

$\underline{10.1016 / \mathrm{j} . \operatorname{cosust} .2013 .06 .006}$

Simons L. 2014. Changing the Food Game: Market Transformation Strategies for Sustainable Agriculture. Greenleaf Publishing Ltd, UK.

Steijn J. 2012. The CEN Initiative on Sustainable and Traceable Cocoa. Presentation at World Cocoa Conference Abidjan

Sustainable Food Lab, 2012. http://www.sustainablefoodlab.org/wpcontent/uploads/2015/12/landscape-deck-for-web-v3.pdf

Tallontire A, Nelson N, Opondo M. 2013. Contingent spaces for smallholder participation in GlobalGAP: insights from Kenyan horticulture value chains. The Geographical Journal, 24 Oct. 2013, Doi:10.1111/geoj.12047

Tallontire A., Opondo M, Nelson V, Martin A. 2011. Beyond the vertical? Using value chains and governance as a framework to analyse private standards initiatives in agri-food chains. Agriculture and Human Values, 28 (3). 427 - 441. ISSN 0889-048X

Terazono E, 2014. Latin American plantations - the future for chocolate? Financial Times online 17.10.2014

UNRISD, 2016. Policy Innovations for Transformative Change: Implementing the 2030 Agenda for Sustainable Development'. Available at:

http://www.unrisd.org/UNRISD/website/document.nsf/(httpPublications)/92AF50726 73F924DC125804C0044F396?OpenDocument

Utting P, van Dijk N, Matheï MA 2014 Social and Solidarity Economy: Is there a New

Economy in the Making? Occasional Paper 10: Potential and Limits of Social and Solidarity Economy’ August 2014. http://www.unrisd.org/utting-et-al.

Vermeulen W, JV, 2015. Self-Governance for Sustainable Global Supply Chains: Can it Deliver the Impacts Needed? Business Stratregy and Environment, 24,73-85, doi: $10.1002 / \mathrm{bse} .1804$

Walker B, Salt D, Reid W, 2006. Resilience thinking: Sustaining People and Ecosystems in a Changing World, Washington D.C.: Island Press. 
Watanatada, P and H. Mak, 2011. Signed, Sealed, Delivered? Beyond certifications and labels. Sustainability. $16^{\text {th }}$ November, 2011. Available at:

http://sustainability.com/our-work/reports/signed-sealed-delivered/ 
Table 1

\section{List of Key Cocoa Sustainability Initiatives In West Africa}

\section{Cocoa Traders/Grinders}

Barry Callebaut - Cocoa Horizons (since 2012)

ADM- Socially \& Environmentally Responsible Agriculture Practices (SERAP)

Program

Cargill- Cocoa Promise

Ecom Trading - Sustainability Program (2009)

Blommer/Olam - GrowCocoa/ Olam Livelihood Charter

Armarajo Trading- Development and Sustainability

Theobroma- Professional Cocoa Farming Program in Cameroon

\section{Manufacturers}

Mars - Sustainable Cocoa Initiative / Vision for Change

Nestle - Cocoa Plan

Hershey - Cocoa Link

Mondelez - Cocoa Life Sustainability Program

Ferrero - Sustainable cocoa

Lindt \& Sprungli - Farming Programme

\section{Standards / Certifications}

Rainforest Alliance - New Business Model Project (NBMP) - Certification

Fairtrade International (FLO) - Certification

UTZ - Certification

Kuapa Kokoo (Ghana) - Cooperative certification

Kavokiva (Cote d'Ivoire) - Cooperative certification

\section{Multi-stakeholder projects}

IDH - Cocoa Program

International Cocoa Organisation (ICCO) - Multiple projects

Multi-stakeholders (Kraft,Armajaro,GTZ, USAID) - Project de Production Durable

de Cacao Certifie - PPDC - Market Oriented Promotion of Certified Sustainbable

Cocoa Production

World Cocoa Foundation - Cocoa Livelihoods Program (CLP) and CocoaAction

World Cocoa Foundation - African Cocoa Initiative

World Cocoa Foundation - Cocoa Management And Progress (CocoaMap) May

2011

IFAD - Cocoa value chain development

\section{Governments and NGOs}

COCOBOD - Ghana Cocoa platform (UNDP)

Solidaridad - Various

CARE/Cargill - Rural Education Project

Source Trust (Armajaro) - Sustainability in Action

Cote d'Ivoire Government/UNDP - Côte d'Ivoire Sustainable Cocoa Initiative

(CISCI)

Ghana Government - African Cocoa Initiative platform 
Nigeria Government - African Cocoa Initiative platform

Cameroon Government - African Cocoa Initiative platform

Cote d'Ivoire Government - African Cocoa Initiative platform

Bill and Melinda Gates Foundation - Agricultural Development initiative 